\title{
Characterization of Endotrypanum (Kinetoplastida: Trypanosomatidae), a Unique Parasite Infecting the Neotropical Tree Sloths (Edentata)
}

\author{
Antonia M Ramos Franco ${ }^{+}$, Gabriel Grimaldi Jr \\ Laboratório de Leishmaniose, Departamento de Imunologia, Instituto Oswaldo Cruz, Av. Brasil 4365, 21045-900 \\ Rio de Janeiro, RJ, Brasil
}

\begin{abstract}
This article reviews current concepts of the biology of Endotrypanum spp. Data summarized here on parasite classification and taxonomic divergence found among these haemoflagellates come from our studies of molecular characterization of Endotrypanum stocks (representing an heterogenous population of reference strains and isolates from the Brazilian Amazon region) and from scientific literature. Using numerical zymotaxonomy we have demonstrated genetic diversity among these parasites. The molecular trees obtained revealed that there are, at least, three groups (distinct species?) of Endotrypanum, which are distributed in Central and South America. In concordance with this classification of the parasites there are further newer molecular data obtained using distinct markers. Moreover, comparative studies (based on the molecular genetics of the organisms) have shown the phylogenetic relationships between some Endotrypanum and related kinetoplastid lineages.
\end{abstract}

Key words: Endotrypanum - Protozoa - Kinetoplastida - Trypanosomatidae - molecular taxonomy - enzyme activities - monoclonal antibodies - enzyme electrophoresis - DNA analyses - mammalian reservoirs sandflies vectors

Biological characteristics of Endotrypanum spp. - Parasitic protozoa of the genus Endotrypanum are unique among the Kinetoplastida in that they infect erythrocytes of their mammalian host. Infection with Endotrypanum appears to be restricted to edentates, principally of forest-dwelling two-toed sloths of the genus Choloepus, but rarer infections with these flagellates seems to occur in three-toed sloths (genus Bradypus) (Fig. 1). As shown in Fig. 2, inside the erythocyte the Endotrypanum assumes an epimastigote or trypomastigote form, while in the sandfly or during in vitro culture the parasite assumes promastigote morphology (Shaw 1992). However, the complete life cycle of Endotrypanum spp. has not been reproduced in experimental studies. Other developmental stages of the parasite may occur within the mammalian host (Deane 1961).

In nature, Endotrypanum parasites are probably transmitted by the bite of infected phlebotomine sandflies (Diptera: Psychodidae). Arias et al.

\footnotetext{
This work was supported in part by the CNPq and Faperj (Brazil).

${ }^{+}$Corresponding author. Fax: +55-21-280.1589. E-mail: franco@gene.dbbm.fiocruz.br

Received 12 November 1998

Accepted 19 January 1999
}

(1985) identified E. schaudinni and other Endotrypanum sp. infections in sandflies and sloths captured in the Amazon Region of Brazil. Studies using kinetoplast DNA probe for detecting parasites in sandflies also demonstrated Endotrypanum infections in Lutzomyia shannoni, Lu. umbratilis and Lu. anduzei (Rogers et al. 1988). Further evidence for the development of Endotrypanum in phlebotomines was obtained by feeding several laboratory-reared sandfly species on infected sloths (Shaw 1964, 1969, 1981, Christensen \& Herrer 1977, 1979). In these studies, infections developing within the insect gut (Shaw 1964, 1969) were similar to those found in wild caught sandflies (Johnson et al. 1963, Arias et al. 1985). Moreover, we have reported (Franco et al. 1997b) the developmental biology of Brazilian strains of Endotrypanum for three sandfly species. Development of Endotrypanum varied for each parasitehost species association. After feeding on culture forms of E. schaudinni, significantly more $L u$. shannoni $(100 \%, 9 / 9)$ became infected than did $L u$. longipalpis $(62.3 \%, 33 / 53)$ or Phlebotomus papatasi $(27.3 \%, 15 / 55)$. The greatest number of infections were in the midgut and hindgut from 6 to 16 days after feeding, but flagellates also were present in the Malpighian tubules. Moreover, distinct development patterns in the sandfly gut were obtained when the Callejon Lu. longipalpis colony was fed on cultures of other Endotrypanum strains. 

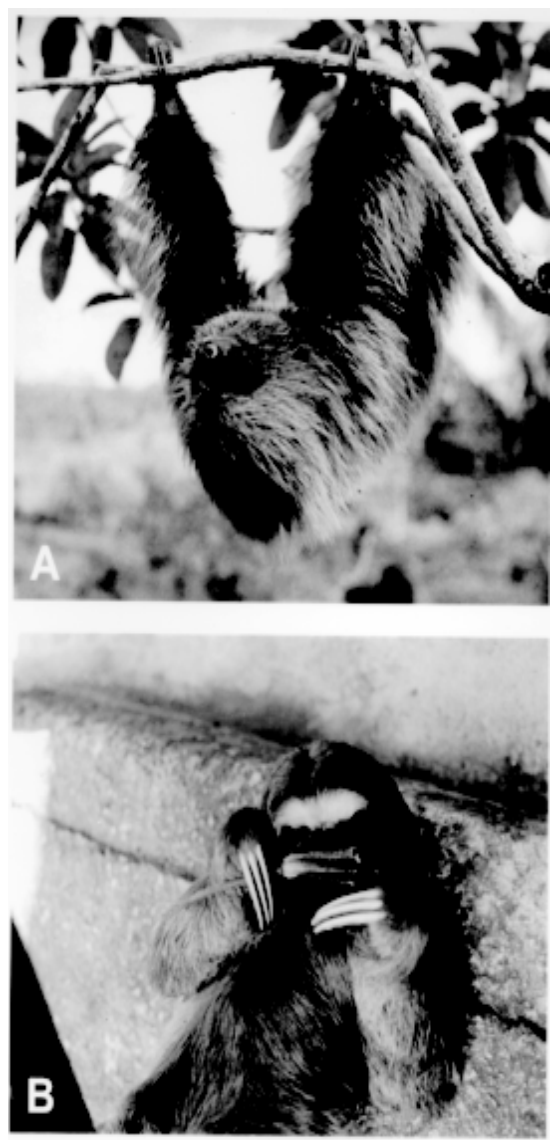

Fig.1: inhabitants of Neotropics: a two-toed sloth, Choloepus didactylus, the major host of Endotrypanum (A) and a threetoed sloth, Bradypus variegatus (B), reservoir-hosts of Endotrypanum in Central and South American Countries.

There were also individual variation in the distribution and survival of parasites within the guts of flies in each group. These data indicate that there is variation in the susceptibility to infection with Endotrypanum among and within sandfly species.

Laboratory diagnosis - The finding that Endotrypanum and Leishmania, as well as other distinct groups of Trypanosoma are commonly found in the same vertebrate and insect hosts in Neotropical forests (Table) has led to an increased interest in developing simple methods to distinguish these parasites for epidemiological purposes. Several methods based on parasite-specific markers have been proposed to discriminate these organisms. Endotrypanum can be distinguished from Leishmania species and other trypanosomatids by enzymatic profiles (Arias et al. 1985, Shaw et al. 1991, Franco et al. 1996b), monoclonal antibodies (Lopes \& McMahon-Pratt 1989, Franco et al. 1997a), total DNA probes (Greig et al. 1989), hybridization probes based on kDNA (Pacheco et al.

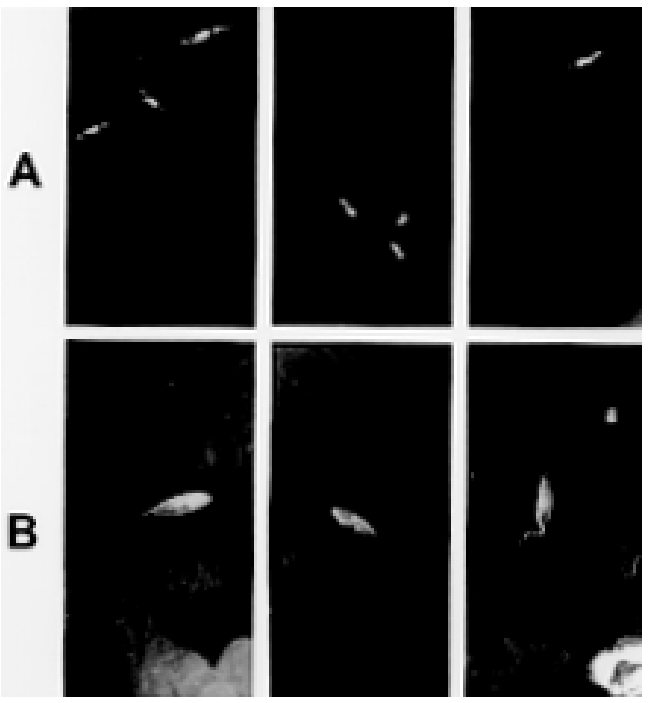

Fig. 2: promastigotes from culture of Endotrypanum (A) and haemoflagellates found in the blood of two-toed sloth, Choloepus juruanus from Rondônia State, BR (B).

1990), mini-exon gene repeats (Fernandes et al. 1993a), lectin reactivity (Lopes et al. 1987) and sialidase/trans-sialidase activities (Medina-Acosta et al. 1994). However, the classical methods used for direct demonstration of the parasite in tissues is difficult because of the paucity of organisms in infected hosts. Work is now in progress to evaluate (employing PCR and serological assays) the prevalence of Endotrypanum and Leishmania infections in sloths captured in distinct sylvan areas of the Neotropics (Pirmez et al. 1997, Mayrink et al. 1998).

Molecular characterization of the genus - The taxonomy of Endotrypanum spp. is still controversial. Since the original description of this parasite, by Mesnil and Brimont in 1908, only two species have been named as E. schaudinni Mesnil and Brimont, 1908 and E. monterogeii, Shaw, 1969. Croft et al. (1980) observed that the mobilities of the enzymes MDH, IDH and ME, in seven stocks of this parasite were different for the strains that had virus-like particles from those that did not. The two groups did not agree with the original identification of E. schaudinni and E. monterogeii since, ultrastructural and biochemical parameters were similar, in contrast to the description by Shaw (1969), who reported serological differences between these species. Lopes et al. (1990), also grouped both species in the same cluster by comparison of nuclear DNA restriction fragment patterns.

The main goal of our studies is to apply an integrated set of approaches towards the characterization of parasites within the genus Endotrypanum and to use this information in a coherent manner 
TABLE

Trypanosomatid parasites commonly found infecting sloths (Edentata: Xenarthra)

\begin{tabular}{|c|c|c|c|c|c|c|c|}
\hline \multirow{2}{*}{$\begin{array}{l}\text { Trypanosomatids/ } \\
\text { Sloths' species }{ }^{b} \\
\end{array}$} & \multicolumn{6}{|c|}{ Geographical distribution $^{a}$} & \multirow{2}{*}{ Reference } \\
\hline & BR & $\mathrm{CO}$ & PA & GF & $\mathrm{EC}$ & $\mathrm{CR}$ & \\
\hline \multicolumn{8}{|l|}{ E. schaudinni } \\
\hline C.didactylus & + & & & + & & & $\begin{array}{l}\text { Mesnil \& Brimont 1908, Deane 1961, Herrer \& } \\
\text { Telford } 1969\end{array}$ \\
\hline C. hoffmanni & & & + & & & & Shaw 1985, Herrer \& Christensen 1980 \\
\hline B. variegatus & & & + & & & + & Shaw 1985 \\
\hline B.tridactylus & + & & & & & & Shaw 1985 \\
\hline \multicolumn{8}{|l|}{ E. monterogeii } \\
\hline C. hoffmanni & & & & & & + & Shaw 1969 \\
\hline \multicolumn{8}{|l|}{ Endotrypanum sp. } \\
\hline Choloepus sp. & & + & & & & & ATCC 1991 \\
\hline Choloepus sp & & & + & & & & ATCC 1991 \\
\hline C.hoffmanni & & & & & & + & Zeledón et al. $1975 \mathrm{c}$ \\
\hline C. juruanus & + & & & & & & Franco et al. $1996 \mathrm{~b}$ \\
\hline \multicolumn{8}{|l|}{ L. panamensis } \\
\hline C.didactylus & & & + & & & & Shaw 1985 \\
\hline C.hoffmanni & & & + & & & + & Zeledón et al. 1975a \\
\hline B. variegatus & & & + & & & + & Zeledón et al. 1975a \\
\hline \multicolumn{8}{|l|}{ L. guyanensis } \\
\hline C. didactylus & + & & & + & & & $\begin{array}{l}\text { Gentile et al. 1981, Lainson et al. 1981, } \\
\text { Shaw 1985, Dedet et al. } 1989\end{array}$ \\
\hline \multicolumn{8}{|l|}{ L. herreri } \\
\hline C. hoffmanni & & & & & & + & Zeledón et al. 1979 \\
\hline B. griseus & & & & & & + & Zeledón et al. 1979 \\
\hline \multicolumn{8}{|l|}{ L.equatorensis } \\
\hline C. hoffmanni & & & & & + & & Grimaldi et al, 1992 \\
\hline \multicolumn{8}{|l|}{ L.colombiensis } \\
\hline C.hoffmanni & & & + & & & & Kreutzer et al. 1991 \\
\hline \multicolumn{8}{|l|}{ L.shawi } \\
\hline C. didactylus & + & & & & & & Lainson et al. 1989 \\
\hline B. tridactylus & + & & & & & & Lainson et al. 1989 \\
\hline \multicolumn{8}{|l|}{ L. braziliensis sp. } \\
\hline B. infuscatus & & & + & & & & Herrer \& Telford 1969, Herrer et al 1973 \\
\hline B.griseus & & & & & & + & Zeledón et al. $1975 \mathrm{c}$ \\
\hline C. hoffmanni & & & + & & & + & $\begin{array}{l}\text { Herrer \& Telford 1969, Herrer et al. 1973, } \\
\text { Zeledón et al. 1975c, Herrer \& Christensen 1980, } \\
\text { Christensen \& de Vasquez } 1982\end{array}$ \\
\hline
\end{tabular}

\begin{tabular}{|c|c|c|c|c|c|c|}
\hline \multicolumn{7}{|l|}{ T. leeuwenhoeki } \\
\hline C. hoffmanni & & + & + & & + & Shaw 1969, Zeledón et al. $1975 b$, Travi et al.1989 \\
\hline B.variegatus & & & + & & + & Shaw 1969, Zeledón et al. 1975b \\
\hline \multicolumn{7}{|l|}{ T. mesnil-brimonti } \\
\hline C.didactylus & + & & & + & & Deane 1961, Shaw 1985 \\
\hline \multicolumn{7}{|l|}{ T.preguici } \\
\hline C. hoffmanni & & & + & & + & Shaw 1969, 1985 \\
\hline B. griseus & & & & & + & Shaw 1969 \\
\hline \multicolumn{7}{|l|}{ T. cruzi } \\
\hline C.hoffmanni & & & + & & & Christensen \& Herrer 1979, Herrer \& Christensen 1980 \\
\hline B.infuscatus & & & + & & & Pipkin 1968 \\
\hline \multicolumn{7}{|l|}{ T.rangeli } \\
\hline C. hoffmanni & & & + & & & Herrer \& Christensen 1980 \\
\hline B. tridactylus & + & & & & & Miles et al. 1983 \\
\hline \multicolumn{7}{|l|}{ T. legeri } \\
\hline B. g. griseus & & & & & + & Montero-Gei 1956, Trejos \& Montero-Gei 1953 \\
\hline
\end{tabular}

$a$ : country of origin: BR: Brazil; CO: Colombia; PA: Panama; GF: French Guiana; EC: Ecuador; CR: Costa Rica; b: designations: [E.= Endotrypanum; C.= Choloepus; B.= Bradypus; L.=Leishmania; T.=Trypanosoma $]$. Original species description (ex. B. infuscatus e B. griseus $=B$. variegatus). 
to address problems of parasite identification and taxonomy, diagnosis and developmental biology. Our results confirm previous studies reporting population diversity within this genus (Lopes et al. 1990).

Trans-sialidase and sialidase activities - By virtue of the differences observed in the rations of these enzyme activities, a large collection of trypanosomatids (comprising the major taxa of these parasites) could be separated into four expression types. Endotrypanum could be clustered into a group which could be easily differentiate from other trypanosomatids by their capacity of expressing comparable levels of both transsialidase and sialidase activities (Medina-Acosta et al. 1994). In general, the measurement of transsialidase and sialidase activities permits the differentiation of parasites frequently found in the same sylvatic vertebrate and invertebrate hosts that are difficult to distinguish, such as Leishmania and Endotrypanum.

Reactivities with monoclonal antibodies Among the new approaches for identifying Endotrypanum is serodeme analysis using specific monoclonal antibodies, Mabs (Lopes \& McMahonPratt 1989). In a recent study (Franco et al. 1997a), an heterogenous population of Endotrypanum strains have been screened against a panel of Mabs derived for selected species of Endotrypanum or Leishmania, to see whether this approach could be used to differentiate/group further among these parasites. Using different immunological assay systems, Mabs considered specific for the genus Endotrypanum [E-24, CXXX-3G5-F12] or strain M6159 of E. schaudinni [E-2, CXIV-3C7-F5] (Lopes \& McMahon-Pratt 1989) reacted variably according to the test used but in the ELISA or immunofluorescence assay both reacted with all the strains tested. Analyses using these Mabs showed antigenic diversity occurring among the Endotrypanum strains, but no qualitative or quantitative reactivity pattern could be consistently related to parasite origin (i.e., host species involved) or geographic area of isolation. Western blot analyses of the parasites showed that these Mabs recognized multiple components and differences existed either in the epitope density or molecular forms associated with the antigenic determinants, which allowed the assignment of the strains to specific antigenic groups.

Multilocus enzyme electrophoresis (MLEE) As a result of using numerical zymotaxonomy for classifying these organisms (Franco et al. 1996b), the taxonomic horizon of Endotrypanum spp. has been widened. We have analyzed enzyme polymorphism among a group of Endotrypanum parasites (17 stocks isolated from sloths in the Amazon Re- gion in Brazil and 6 reference strains). The 16 enzymic loci were analyzed, and the strains were classified into zymodemes, each representing parasites with unique enzyme profiles. Using numerical analyses the genus was shown to be monophyletic and the 12 zymodemes characterized could be divided into three groups (A, B, C) (Fig. 3). The data indicate that $E$. schaudinni is a species complex. The heterogeneous population of parasites showed, however, no correlation with the origin of Endotrypanum stocks. Eight isolates from the State of Rondônia (Brazil) and a parasite strain from Panama were clustered together into a zymodeme (IOC/EZ01), which was phenetically closely related to the E. monterogeii from Costa Rica. All these data reinforce the discussion about the existence of the later parasite species.

Minicircle kDNA heterogeneity and molecular karyotypes - Comparisons of kDNA restriction enzyme fragments profiles from strains representing selected Endotrypanum zymodemes were carried out by polyacrylamide gradient gel electrophoresis. As the degree of heterogeneity within minicircles varied among species or strains of Endotrypanum, the stocks could be clustered into distinct groups of parasites, according to the major sequence classes (minicircle fragments or digests) released by the restriction endonucleases tested (Franco et al. 1996a). In parallel study using PFGE and appropriate gel running conditions, chromosomes were polymorphic in number (1025 ) and size (290-2,200 kb) of bands among parasites of this genus. Distinct karyotypes were constructed among E. schaudinni, E. monterogeii and Endotrypanum sp. strains. All of the isolates (5) of Endotrypanum sp. from the same species of sloth (C. juruanus) and geographical origin (Rondônia, Brazil) had the same karyotype (Franco et al. 1992). Interesting, these parasites were grouped in the same zymodeme (EZ01) with two other stocks originating from Central America (Franco et al. 1996b). However, RAPD analysis using selected primer was able to differentiate the EZ01 parasites, but the strains did not group on the basis of their geographic origin (Franco et al. 1998a).

Evolutionary links among parasites and taxonomic problems - The difficult taxonomy of Endotrypanum spp. is mainly because the parasite life cycle is unknown. Although this genus is unique among the Trypanosomatidae in that the parasites are found inside the erythrocyte of the mammalian host, both forms (epimastigotes of $E$. schaudinni and trypomastigotes of E. monterogeii) are found rarely in infected sloths. Endotrypanum spp. have other distinct form in their lyfe cycle: a motile flagellated promastigote stage that lives extracellularly within the alimentary tract of the 
vector, at least in experimentally infected phlebotomine sandfly (Franco et al. 1997b).

The Endotrypanum shares many characters with other trypanosomatids, particularly those of the genus Leishmania (Shaw 1992). Phylogenetic reconstruction studies of the various kinetoplastid lineages (Fernandes et al. 1993b, Maslov \& Simpson 1995) have shown that Leishmania and Endotrypanum are more closely related organisms to each other than either is to T. cruzi. The genetic similarity between Endotrypanum and leishmanial parasites, such as $L$. $(L$.) herreri, $L .(L)$. hertigi/ L. $(L)$. deanei, L. (V.) colombiensis or L. (V.) equatorensis was demonstrated by $(i)$ sequencing comparisons of the small subunit of ribosomal RNA and RNA Polymerase II genes (Croan \& Ellis 1996, Noyes et al. 1996, 1997, Croan et al. 1997), (ii) numerical zymotaxonomy, (iii) intergenic region typing of the internal transcribed spacers of the rRNA genes, (iv) minicircle kDNA heterogeneity analysis, and $(v)$ measurement of the sialidase activites of the parasites (Cupolillo et al. 1998). The data show that $L$. (L.) hertigi/L. (L.) deanei (Herrer 1971, Lainson \& Shaw 1977) are genetically closest to the Endotrypanum/L. $(L$. herreri group. Interesting, $L$. (L.) herreri was genetically closer to Endotrypanum than to the pathogenic Leishmania species (Croan et al. 1997, Noyes et al. 1997). The former parasite was originally isolated from two (C. hoffmanni) and three-toed (B. griseus) sloths, and sandflies (Lu. trapidoi, $L u$. ylephiletor and Lu. shannoni) in Costa Rica (Zeledón et al. 1979). Studies employing monoclonal antibodies have also shown antigenic similarities among these parasites (Grimaldi et al. 1992, Shaw 1992, Franco et al. 1997a).

Moreover, studies by Touch-down PCR with primers from kinetoplastid housekeeping genes (ribosomal $\mathrm{P}$ proteins and repetitive sequences, SIRE) examine the relationships among Endotrypanum $(\mathrm{N}=22$ strains, comprising the major taxa of this genus) and $L$. (L.) herreri (ISHA/ CR/74/LV341 and IYLE/CR/74/LV342 strains, both isolated from sandflies, and $\mathrm{MCHO} / \mathrm{CR} / 74 /$ LV344 strain, isolated from sloth). The data reveal differences among the leishmanial strains, but showing closed genetic similarity between LV342 and Endotrypanum strains clustered within the same group (group A) by zymodeme analysis (Franco et al. 1996b). However, both strains LV341 and LV344 were distinct from all Endotrypanum stocks analyzed (Franco et al. 1998b). Comparative phylogenetic reconstruction studies are in progress to address the evolutionary links among these related kinetoplastid lineages.

The known vertebrate hosts of Endotrypanum spp., two and three-toed sloths, are considered as unique examples of South American fauna and they evolved some 60-70 million years ago during the Palaeocene period. The separation between these two genera of sloths occurred later during the Miocene period and their presence in Central America, is thought to be a result of migration from South America (Webb 1985, Sarich 1985). In Choloepus the body temperature ranges from $24^{\circ}$ to $33^{\circ} \mathrm{C}$. This variation results in a geographical barrier to these mammals (Nowak 1991) and consequently to the parasites. Lopes et al. (1990) based on results of restriction fragment hybridization conclude that Endotrypanum originated in South America. Considering these observations, zymodeme EZ01 (Fig. 3) has migrated towards Central America and the parasites isolated in this area are representative of the most recent group (group A). Moreover, the results suggest that the dispersal of the genus Endotrypanum has arisen from group $\mathrm{C}$, which is probably the most ancient organism (Franco et al. 1996b).

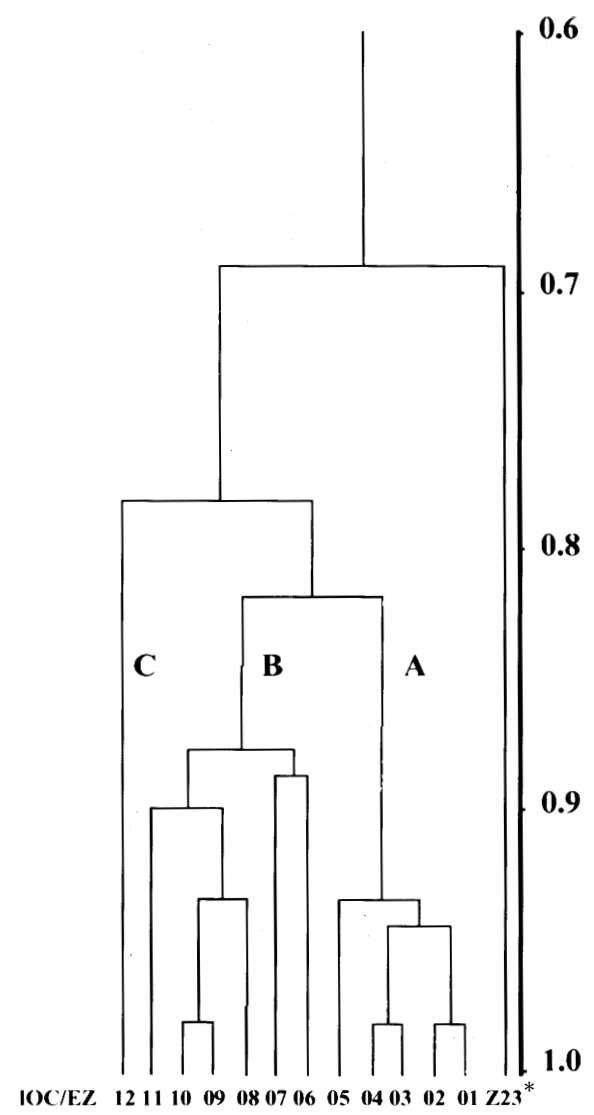

Fig. 3: phenetic analysis of enzyme data from Endotrypanum stoks. The Simple Matching Coefficient of Similarity was calculated between all combinations of pairs of strains and the similarity matrix transformed into a dendogram by the UPGMA algorithm.

(* Corresponds to Leishmania zymodeme - IOC/Z23). 


\section{REFERENCES}

Arias JR, Miles MA, Naiff RD, Póvoa MM, De Freitas RA, Biancardi CB, Castellon EG 1985. Flagellate infection of Brazilian sandflies (Diptera: Psychodidae): isolation in vitro and biochemical identification of Endotrypanum and Leishmania. Am J Trop Med Hyg 34: 1098-1108.

ATCC - American Type Culture Collection 1991. Catalogue of Protists. 17th ed., 20 pp.

Christensen HA, Herrer A 1977. The use of phlebotomine sand flies in xenodiagnosis. Coll Inter Centre Nat Rec Sci 239: 129-130.

Christensen HA, Herrer A 1979. Susceptibility of sandflies (Diptera: Psychodidae) to Trypanosomatidae from two-toed sloths (Edentata: Bradypodidae). J Med Entomol 16: 424-427.

Christensen HA, Vasquez AMD 1982. The tree-buttress biotope: a pathobiocenose of Leishmania braziliensis. Am J Trop Med Hyg 31: 243-251.

Croan D, Ellis J 1996. Phylogenetic relationships between Leishmania, Viannia and Sauroleishmania inferred from comparison of a variable domain within the RNA polymerase II largest subunit gene. $\mathrm{Mol}$ Biochem Parasitol 79: 97-102.

Croan DG, Morrison DA, Ellis JT 1997. Evolution of the genus Leishmania revealed by comparison of DNA and RNA polymerase gene sequences. Mol Biochem Parasitol 89: 149-159.

Croft SL, Chance ML, Gardener PJ 1980. Ultrastructural and biochemical characterization of stocks of Endotrypanum. Ann Trop Med Parasitol 74: 585589.

Cupolillo E, Pereira LOR, Fernandes O, Catanho MP, Pereira JC, Medina-Acosta E, Grimaldi Jr G 1998. Genetic data showing evolutionary links between Leishmania and Endotrypanum. Mem Inst Oswaldo Cruz 93: 677-683.

Deane LM 1961. Tripanosomatídeos de mamíferos da região Amazônica. I. Alguns flagelados encontrados no sangue de mamíferos silvestres do Estado do Pará. Rev Inst Med Trop São Paulo 3: 15-28.

Dedet JP, Gay F, Chatenay G 1989. Isolation of Leishmania species from wild mammals in French Guiana. Trans $R$ Soc Trop Med Hyg 83: 613-615.

Fernandes O, Degrave W, Campbell DA 1993a. The mini-exon gene: a molecular marker for Endotrypanum schaudinni. Parasitology 107: 219-224.

Fernandes AP, Nelson K, Beverley SM 1993b. Evolution of nuclear ribosomal RNAs in kinetoplastid protozoa: perspectives on the age and origins of parasitism. Proc Natl Acad Sci USA 90: 11608-11612.

Franco AMR, Andrade LO, Moreira CFS, Machado GMC, Macedo AM, Grimaldi Jr G 1998a. Random amplified polymorphic DNA fingerprinting (RAPD) analysis reveals the genetic heterogeneous population structure of Endotrypanum parasites. Mem Inst Oswaldo Cruz 93: 198.

Franco AMR, Machado GMC, Moreira CFS, Mayrink NA, Grimaldi Jr G 1996a. Analysis of minicircle kDNA heterogeneity in Endotrypanum indicate diversity within this genus. Mem Inst Oswaldo Cruz 91: 96.
Franco AMR, Machado GMC, Naiff RD, Moreira CFS, McMahon-Pratt D, Grimaldi Jr G 1997a. Characterization of Endotrypanum parasites using specific monoclonal antibodies. Mem Inst Oswaldo Cruz 92: 63-68.

Franco AMR, Momen H, Naiff RD, Moreira CFS, Deane MP, Grimaldi Jr G 1996b. Enzyme polymorphism in Endotrypanum and numerical analysis of isoenzyme data. Parasitology 113: 39-48.

Franco AMR, Moreira CFS, Santamgelo A, MedinaAcosta E, Schijman A, Grimaldi Jr G 1998b. On the identity of Leishmania herreri and enigmatic Endotrypanum parasites infecting sloths and Phlebotomine sandflies from sylvan areas of the Neotropics. Mem Inst Oswaldo Cruz 93: 341.

Franco AMR, Tavares CC, Moreira CFS, Carrera CC, Deane MP, Grimaldi Jr G 1992. Molecular karyotype analysis of reference strains and isolates of Endotrypanum from sloths in the Amazon Region of Brazil. Mem Inst Oswaldo Cruz 87: 246.

Franco AMR, Tesh RB, Guzman H, Deane MP, Grimaldi Jr G 1997b. Development of Endotrypanum (Kinetoplastida: Trypanosomatidae) in experimentally infected Phlebotomine sand flies. J Med Entomol 34: 198-192.

Gentile B, Le Pont F, Pajot FX, Besnard R 1981. Dermal leishmaniasis in French Guiana: the sloth (Choloepus didactylus) as a reservoir host. Trans $R$ Soc Trop Med Hyg 75: 612-613.

Greig SR, Akinsehinwa FA, Ashall F, Lainson R, Shaw JJ, Miles MA, Barker DC 1989. The feasibility of discrimination between Leishmania and Endotrypanum using total DNA probes. Trans $R$ Soc Trop Med Hyg 83: 196-197.

Grimaldi Jr G, Kreutzer RD, Hashiguchi Y, Gomez EA, Mimory T, Tesh RB 1992. Description of Leishmania equatorensis sp. n. (Kinetoplastida: Trypanosomatidae), a new parasite infecting arboreal mammals in Ecuador. Mem Inst Oswaldo Cruz 87: 221-228.

Herrer A 1971. Leishmania hertigi sp.n. from the tropical porcupine, Coendou rothschildi Thomas. J Parasitol 57: 626-629.

Herrer A, Christensen HA 1980. Leishmania braziliensis in the Panamanian two-toed sloth, Choloepus hoffmanni. Am J Trop Med Hyg 29: 1196-1200.

Herrer A, Telford SR 1969. Leishmania braziliensis isolated from sloths in Panama. Science 164: 14191420.

Herrer A, Christensen HA, Beumer RJ 1973. Reservoir hosts of cutaneous leishmaniasis among Panamanian forest mammals. Am J Trop Med Hyg 22: 585-591.

Johnson PT, McConnell E, Hertig M 1963. Natural infections of leptomonad flagellates in Panamanian Phlebotomus sandflies. Exp Parasitol 14: 107-122.

Kreutzer RD, Corredor A, Grimaldi Jr G, Grogl M, Rowton ED, Young DG, Morales A, McMahonPratt D, Guzman H, Tesh R 1991. Charaterization of Leishmania colombiensis sp. n. (Kinetoplastida: Trypanosomatidae), a new parasite infecting humans, animals, and phlebotomine sand flies in Colombia and Panama. Am J Trop Med Hyg 44: 662-675. 
Lainson R, Shaw JJ 1977. Leishmania of neotropical porcupines: Leishmania hertigi deanei nov. subsp. Acta Amazonica 7: 51-57.

Lainson R, Braga RR, De Souza AAA, Póvoa MM, Ishikawa EAY, Silveira FT 1989. Leishmania (Viannia) shawi sp. n., a parasite of monkeys, sloths and procyonids in Amazonian Brazil. Ann Parasit Hum Comp 64: 200-207.

Lainson R, Shaw JJ, Ready PD, Miles MA, Póvoa MM 1981. Leishmaniasis in Brazil. XVI. Isolation and identification of Leishmania species from sandflies, wild mammals and man in North Pará state, with particular reference to Leishmania braziliensis guyanensis, causative agent of "pian-bois". Trans R S Trop Med Hyg 75: 530-536.

Lopes AHCS, McMahon-Pratt D 1989. Monoclonal antibodies specific for members of the genus Endotrypanum. J Protozool 36: 354-361.

Lopes AHCS, Esteves MJG, Angluster J, Andrade AFB 1987. Lectin binding to surface saccharides on Endotrypanum strains. Mem Inst Oswaldo Cruz 82: 42.

Lopes AHCS, Iovannisci D, Petrillo-Peixoto M, McMahon-Pratt D, Beverley SM 1990. Evolution of nuclear DNA and the occurrence of sequences related to new small chromosomal DNAs in the trypanosomatid genus Endotrypanum. Mol Biochem Parasitol 40: 151-162.

Maslov DA, Simpson L 1995. Evolution of Parasitism in Kinetoplastid Protozoa. Parasitol Today 11: 3032.

Mayrink AN, Franco AMR, Grimaldi Jr G 1998. Serodiagnostic survey of Endotrypanum and Leishmania infections in two and three-toed sloths using a micro-Elisa assay as a screening test. Mem Inst Oswaldo Cruz 93: 274.

Medina-Acosta E, Franco AMR, Jansen AM, Sampol M, Nevés N, Pontes-de-Carvalho L, Grimaldi Jr G, Nussenzweig V 1994. Trans-sialidase and sialidase activities discriminate between morphologically indistinguishable trypanosomatids. Eur J Biochem 225: 333-339.

Mesnil F, Brimont E 1908. Sur un hematozoaire nouveau (Endotrypanum n.gen.) d'un edente de la Guyane. C R Soc Biol 65: 581.

Miles MA, Arias JR, Valente AS, Naiff RD, De Souza AA, Póvoa MM, Lima JA, Cedillos RA 1983. Vertebrate hosts and vectors of Trypanosoma rangeli in the Amazon Basin of Brazil. Am J Trop Med Hyg 32: 1251-1259.

Montero-Gei F 1956. Contribución al estudio de Endotrypanum schaudinni (Trypanosomatidae). Rev Biol Trop 4: 41-68.

Noyes HA, Camps AP, Chance ML 1996. Leishmania herreri (Kinetoplastida: Trypanosomatidae) is more closely related to Endotrypanum (Kinetoplastida: Trypanosomatidae) than to Leishmania. Mol Biochem Parasitol 80: 119-123.

Noyes HA, Arana BA, Chance ML, Maingon R 1997. The Leishmania hertigi (Kinetoplastida: Trypanosomatidae) complex and the lizard Leishmania: their classification and evidence for a neotropical origin of the Leishmania-Endotrypanum clade. J Euk Microbiol 44: 511-517.

Nowak RM 1991. Order Xenarthra. Walker's Mammals of the World, p. 515-527, Vol. I, Fifth edition. The Johns Hopkins University press Ltd., Baltimore and London.

Pacheco RS, Thomaz N, Momen H 1990. kDNA crosshybridization between Endotrypanum and peripylarian Leishmania. Trans R Soc Trop Med Hyg 84: 531

Pipkin AC 1968. Domicillary reduviid bugs and the epidemiology of Chaga's disease in Panama (Hemiptera: Reduviidae: Triatominae). J Med Entomol 5: 107-124.

Pirmez C, Oliveira-Neto MP, Franco AMR, Meneses C, Rangel E, Mayrink A, Silva-Gonçalves AJ, Fernandes O, Grimaldi G 1997. Edentates as a possible reservoir of $L$. (V.) braziliensis in an endemic area of Rio de Janeiro. Mem Inst Oswaldo Cruz 92: 119.

Rogers WO, Burnheim PF, Wirth DF 1988. Detection of Leishmania within sand flies by kinetoplast DNA hybridization. Am J Trop Med Hyg 39: 434-439.

Sarich VM 1985. Xenarthran systematics: albumin immunological evidence, p. 77-81. In The Evolution and Ecology of Armadillos, Sloths and Vermilingues, GG Montegomery, Smithsonian Institution Press, Washington, D.C., London.

Shaw JJ 1964. A possible vector of Endotrypanum schaudinni of the sloth Choloepus hoffmanni in Panama. Nature Lond 201: 417- 418.

Shaw JJ 1969. The Haemoflagellates of Sloths. London School of Hygiene and Tropical Medicine Memoir, No. 13, H.K. Lewis and Co. Ltd., London, 132 pp.

Shaw JJ 1981. The behaviour of Endotrypanum schaudinni (Kinetoplastida: Trypanosomatidae) in three species of laboratory-bred Neotropical sandflies (Diptera: Psychodidae) and its influence on the classification of the genus Leishmania, p. 232-241. In Parasitological Topics, Soc Protozool Special Publ. No. 1, Canning, E.U.

Shaw JJ 1985. The haemoflagellates of sloths, vermilinguas (anteaters), and armadillos, p. 279292. In The Evolution and Ecology of Armadillos, Sloths and Vermilingues, GG Montgomery, Smithsonian Institution Press, Washington DC.

Shaw JJ 1992. Endotrypanum, a unique intraerythrocytic flagellate of New World tree sloths. An evolutionary link or an evolutionary backwater? Ciên Cult 44:107-116.

Shaw JJ, Braga RR, Lainson R, Ishikawa EAY 1991. Aconitate hydratase (ACON), na enzyme that distinguishes Leishmania of the subgenus Viannia from other trypanosomatids. Trans $R$ Soc Trop Med Hyg 85: 597-589.

Travi BL, Zea A, D'Alessandro A 1989. Trypanosoma (Herpetosoma) leeuwenhoeki in Choloepus hoffmanni and Didelphis marsupialis of the pacific coast of Colombia. J Parasitol 75:218-224.

Trejos A, Montero-Gei F 1953. Estudios sobre tripanosómidos de Edentata en Costa Rica. I. Trypanosoma legeri en Bradypus griseus. Rev Biol Trop 


\section{1: 21-27.}

Webb SD 1985. The interrelationships of the tree sloths and ground sloths, p. 105-112, In The Evolution and Ecology of Armadillos, Sloths and Vermilinguas, GG Montgomery, Smithsonian Institution Press, Washington, London.

Zeledón R, Ponce C, Murillo J 1979. Leishmania herreri sp. n. from sloths and sandflies of Costa Rica. $J$ Parasitol 65: 273- 279.
Zeledón R, Ponce C, Ponce E De 1975a. The isolation of Leishmania herreri sp.n. from sloths in Costa Rica. Am J Trop Med Hyg 24: 706-707.

Zeledón R, Ponce C, Ponce E De 1975b. Isolation of Trypanosoma rangeli from Costa Rican sloths. Am Soc Parasit, Program and Abstracts 60.

Zeledón R, Ponce C, Ponce E De 1975c. The isolation of Leishmania braziliensis from sloths in Costa Rica. Am J Trop Med Hyg 24: 706-707. 